\title{
SHRIMP zircon ages of eclogites in the Stak massif, northern Pakistan.
}

\author{
Nicolas Riel ${ }^{1}$, Kéiko Hattori ${ }^{2}$, Stéphane Guillot ${ }^{1}$, Nicole Rayner ${ }^{3}$, Bill Davis ${ }^{3}$, \\ Mohamad Latif ${ }^{4}$ and Allah B Kausar ${ }^{4}$
}

1 University of Grenoble, OSUG - CNRS, BP 53, 38041 Grenoble cedex 9, FRANCE

2 University of Ottawa, Dept of Earth Sciences, Ottawa, Ontario, K1N 6N5, CANADA

3 Geological Survey of Canada, 601 Booth Street, Ottawa, Ontario, K1A 0E8, CANADA

${ }^{4}$ Geological Survey of Pakistan-Northern Area, Plot No. 84, H-8/1, Islamabad, PAKISTAN

*For correspondence, email: nicolas.riel@uif-grenoble.fr, khattori@uottawa.ca

Retrogressed eclogites were reported by Le Fort et al. (1997) near the village of Stak from the Indus suture zone on the eastern side of the Nanga Parbat-Haramosh massif. The eclogite assemblage occurs in lenses and boudins in the matrix of phengite-bearing metasedimentary rocks and marbles. It is composed of pyrope rich garnet, omphacitic pyroxene, phengite, dolomite and rutile. New P-T estimates give a minimum pressure of $\sim 2.3 \mathrm{GPa}$ for $750^{\circ} \mathrm{C}$ (e.g. Guillot et al., this volume). The eclogites are distinctly mafic in mineralogy and compositions compared with UHP rocks at Tso Morari and Kaghan Valley both of them originated from the crustal material of the Indian continental margin (Guillot et a. 1997, O'Brien et al. 2001). The eclogites in the Stak massif contain high $\mathrm{Mg}(\sim 9 \mathrm{wt} \%)$ and low $\mathrm{Si}(\sim 48 \mathrm{wt} \%)$, yet high incompatible elements, including fluid-immobile elements. The bulk chemical compositions suggest that they are alkaline mafic igneous rocks most likely associated with a mantle plume.
Well-crystallized zircon grains are common within and adjacent to garnet in the eclogites. We hand-picked 34 grains, and mounted them into an Epoxy resin together with zircon grains with known ages from Fish Canyon Tuff, and Temara 2 for the CL-SEM examination and SHRIMP age determination at the Geological Survey of Canada in Ottawa. Zircon grains yielded $206 \mathrm{~Pb} / 238 \mathrm{U}$ ages varying from 80.0 to $48.1 \pm 1.4 \mathrm{Ma}$ with peaks at around $51.3 \pm 0.7 \mathrm{Ma}$ and $60.4 \pm 0.6 \mathrm{Ma}$ in the age distribution histogram. Outer rims of several grains are $51 \mathrm{Ma}$, suggesting that this likely represents the age of the eclogitization. The timing of the eclogitization at Stak is comparable to the $53.3+-0.7 \mathrm{Ma}$ age for the Tso Morari massif (Leech et al. 2005) but older than the age of 46.2+-0.7 Ma for the Kaghan unit (Kaneko et al. 2003, Parrish et al. 2006). The protolith of the Stak eclogites is most likely between 70 and $80 \mathrm{Ma}$ and younger ages are due to varying degrees of $\mathrm{Pb}$-loss during the metamorphism because grains with

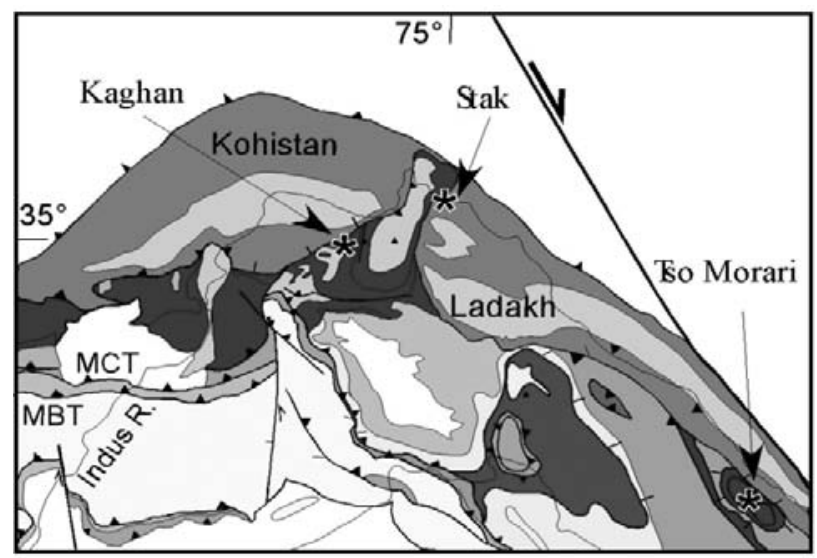

FIGURE 1. The location of the Stak eclogites

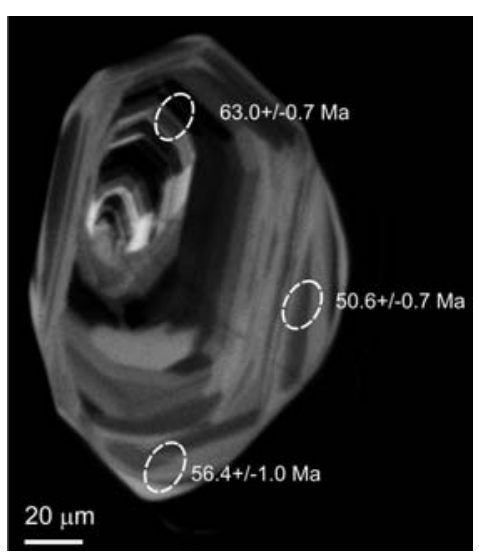

FIGURE 2. CL-SEM image of zircon grain16 showing the areas for the SHRIMP age determination. The overgrowth yielded the age of the eclogitization, whereas theinterior with oscillatory zoning shows two different ages. These ages are interpreted as reset ages by $\mathrm{Pb}$ loss during the metamorphism.

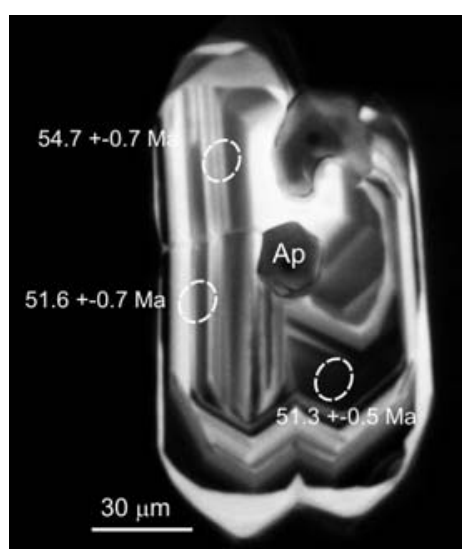

FIGURE 3. CL-SEM image of zircon grain 8 showing the areas for the SHRIMP age determination $A p=$ apatite 
well-preserved igneous textures, such as oscillatory zoning and sector twinning, yielded different ages among different grains and even within individual grains. The data suggest either the protolith is igneous rocks associated with the Reunion hotspot on the distal part of the Indian continental margin (e.g. Mahoney et al. 2002) or a seamount/oceanic island formed on the Tethys Sea.

One small grain with low $\mathrm{Th} / \mathrm{U}$ shows $31.3 \pm 0.4$ and 31.7 $\pm 0.5 \mathrm{Ma}$. This is interpreted as the secondary zircon formed in a late aplite-pegmatite dyke common in the area (Patterson and Windley 1985).

References

O'Brien PJ, N Zotov, R Law, MA Khan and MQ Jan. 2001. Coesite in Himalayan eclogite and implications for models of India-Asia collision. Geology 29 (5): 435-438

Guillot S, J de Sigoyer, JM Lardeaux and G Mascle. 1997. Eclogitic metasediments from the Tso Morari area (Ladakh, Himalaya): Evidence for continental subduction during India-Asia convergence. Contribution to Mineralogy and Petrology 128: 197-212

Guillot S, N Riel, K Hattori, S Desgreniers, Y Rolland, J Van Melle, M Latif, AB Kausar and A Pĕcher. 2008. New occurrence of eclogitic continental rocks in NW Himalaya: Tha Stak massif in north Pakistan. Himalayan Journal of Sciences 5(7): 57
Kaneko Y, I Katayama, H Yamamoto, K Misawa, M Ishikawa, HU Rehman AB Kausar and K Shiraishi. 2003. Timing of Himalayan ultrahighpressure metamorphism: sinking rate and subduction angle of the Indian continental crust beneath Asia. Journal Metamorphic Geology 21: 589-599

Le Fort P, S Guillot and A Pêcher. 1997. HP metamorphic belt along the Indus sutuer zone of NW Himalaya: new discoveries and significance. Compte Rendus de l'Académie des Sciences 325: 773-778.

Leech, ML, S Singh, AK Jain, SL Klemperer and RM Manickavasagam. 2005. The onset of India-Asia continental collision: Early, steep subduction required by the timing of UHP metamorphism in the western Himalaya. Earth Planet Science Letters 234: 83-97

Mahoney JJ, RA Duncan, W Khan, E Gnos, GR McCormick. 2002. Cretaceous volcanic rocks of the South Tethyan suture zone, Pakistan: implications for the Réunion hotspot and Deccan Traps. Earth Planet Science Letters 203: 295-310

Parrish RR, SJ Gough, MP Searle, DJ Waters. 2006. Plate velocity exhumation of ultrahigh-pressure eclogite in the Pakistan Himalaya. Geology 34: 989992

Patterson MG and BF Windley. 1985. Rb-Sr dating of the Kohistan arcbatholith in the Trans-Himalaya of north Pakistan, and tectonic implications. Earth Planet Science Letters 74: 45-57 